\title{
Poly(methylmethacrylate) — magnesium triflate gel polymer electrolyte for solid state magnesium battery application
}

\author{
G. Girish Kumar, N. Munichandraiah* \\ Department of Inorganic and Physical Chemistry, Indian Institute of Science, Bangalore 560 012, India
}

Received 4 October 2000; received in revised form 25 September 2001

\begin{abstract}
A gel polymer electrolyte (GPE) film of poly(methylmethacrylate) and magnesium triflate is studied in view of its potential application in a solid state rechargeable magnesium battery. Experimental data of a.c. impedance and cyclic voltammetric studies of symmetrical cells made of blocking and non-blocking electrodes, and also data of charge/discharge cycles of $\mathrm{Mg} / \mathrm{GPE} / \mathrm{MnO}{ }_{2}$ cells are reported. The composition of the GPE is optimized in view of a minimum quantity of the liquid components (propylene carbonate and ethylene carbonate) required for the gel formation and a maximum conductivity. Specific conductivity $(\sigma)$ of the GPE of optimum composition is $(4.2 \pm 0.45) \times 10^{-4} \mathrm{~S} \mathrm{~cm}^{-1}$ at $20^{\circ} \mathrm{C}$. The $\sigma$ values follow the Arrhenius equation and the activation energy for GPE of optimum composition is $0.038 \mathrm{eV}$. The effects of temperature and ageing on $\mathrm{Mg} / \mathrm{GPE}$ interface are studied. Discharge capacity of about $90 \mathrm{mAh} \mathrm{g}^{-1}$ of $\mathrm{MnO}_{2}$ is obtained during the discharge of $\mathrm{Mg} / \mathrm{GPE} / \mathrm{MnO}_{2}$ cells. On repeated charge/discharge cycling of the cell, the discharge capacity decreases to about $70 \mathrm{mAh} \mathrm{g}^{-1}$. The cycle-life is limited by the problems associated with passivation of the Mg surface. (C) 2002 Elsevier Science Ltd. All rights reserved.
\end{abstract}

Keywords: A.c. impedance spectroscopy; Cyclic voltammetry; Gel polymer electrolyte; Ionic conductivity; $\mathrm{Mg} / \mathrm{GPE} / \mathrm{MnO} 2$ cells

\section{Introduction}

Extensive investigations on solid polymer electrolytes (SPE) have been under progress in view of potential application in solid state batteries [1-3]. By employing a thin film of SPE in place of a conventional liquid electrolyte, several advantages are anticipated. Of these, enhancement in energy density occupies primary importance. For the purpose of using in a solid state battery, a SPE film needs to possess several properties, among which a high ionic conductivity and a good mechanical stability are of essential importance. Although a polyethyleneoxide (PEO) - based SPE film possesses a good mechanical strength and dimensional stability, conductivity (specific conductivity, $\sigma \approx 1 \times 10^{-8} \mathrm{~S}$ $\mathrm{cm}^{-1}$ ) at ambient temperature is very low [4]. In order to achieve high conductivity, gel polymer electrolytes (GPE) are investigated [5]. A GPE essentially contains a liquid electrolyte retained in a polymer gel. Although

\footnotetext{
* Corresponding author. Tel.: +91-80-3092828; fax: +91-803600683.

E-mail address: muni@ipc.iisc.ernet.in (N. Munichandraiah).
}

the mechanical strength of a GPE is less than that of a SPE [6], its $\sigma$ at ambient temperature is in the range of $1 \times 10^{-4}-1 \times 10^{-3} \mathrm{~S} \mathrm{~cm}^{-1}$, which may be sufficient for battery application.

In electromotive force series, $\mathrm{Mg}$ with an electrode potential of $-2.3 \mathrm{~V}$ versus SHE is positioned next to lithium and its electrochemical equivalence (2.2 Ah $\mathrm{g}^{-1}$ ) is also high. Therefore, $\mathrm{Mg}$ is an attractive anode material and it has been employed in aqueous primary and reserve batteries [7]. Studies on solid state rechargeable magnesium batteries are interesting in comparison with lithium batteries on account of the following advantages: (1) natural resources of the $\mathrm{Mg}$ are plentiful and, thus, it is much cheaper than the $\mathrm{Li}$; (2) the magnesium metal is more stable than the lithium. It can be handled safely in oxygen and humid atmospheres unlike lithium, which requires a high purity argon or helium atmosphere. Therefore, safety problems associated with the $\mathrm{Mg}$ metal are minimal; (3) the ionic radii of $\mathrm{Li}^{+}$and $\mathrm{Mg}^{2+}$ are comparable in magnitude [8]. Hence, $\mathrm{Li}^{+}$ions in insertion compounds can easily be replaced by $\mathrm{Mg}^{2}+$ ions. Investigations related to solid state rechargeable magnesium batteries, however, are 
scarce in the literature [9]. We have recently reported studies related to this topic based on $\mathrm{Mg}$ metal anode and polyacrylonitrile GPE [10-12]. In the present study, a GPE of poly(methylmethacrylate) (PMMA) is investigated for ionic conductivity, $\mathrm{Mg} / \mathrm{GPE}$ interfacial stability and for assembly of a solid-state $\mathrm{Mg}$ cell.

\section{Experimental}

Propylene carbonate (PC), ethylene carbonate (EC), magnesium trifluoromethanesulfonate (magnesium trifiate, MgTr) and PMMA were purchased from Aldrich. The solvents $\mathrm{PC}$ and EC were vacuum-distilled at $110{ }^{\circ} \mathrm{C}$, and $\mathrm{MgTr}$ was vacuum dried at $100{ }^{\circ} \mathrm{C}$ before use. A suspension containing the required amounts of PMMA, PC, EC and MgTr in a glass petri-dish was heated at $80{ }^{\circ} \mathrm{C}$ in $\mathrm{Ar}$ atmosphere for about $2 \mathrm{~min}$. Subsequent to cooling, a GPE film formed. Equal quantities by weight of $\mathrm{PC}$ and $\mathrm{EC}$ were used in all experiments. For the purpose of arriving at an appropriate composition, several GPE films were prepared by varying the quantities of $(\mathrm{PC}+\mathrm{EC})$ and $\mathrm{MgTr}$ in a constant quantity of PMMA. An appropriate composition is considered to be the one, which uses a minimum of liquid components and yields a maximum of conductivity $(\sigma)$. Circular specimens (area $=0.8 \mathrm{~cm}^{2}$ ) of magnesium were sectioned out of a sheet of Mg AZ21 alloy (DOW Chemical Company). These specimens were polished with successive grades of emery paper to a smooth finish, washed thoroughly in acetone and dried at ambient conditions.

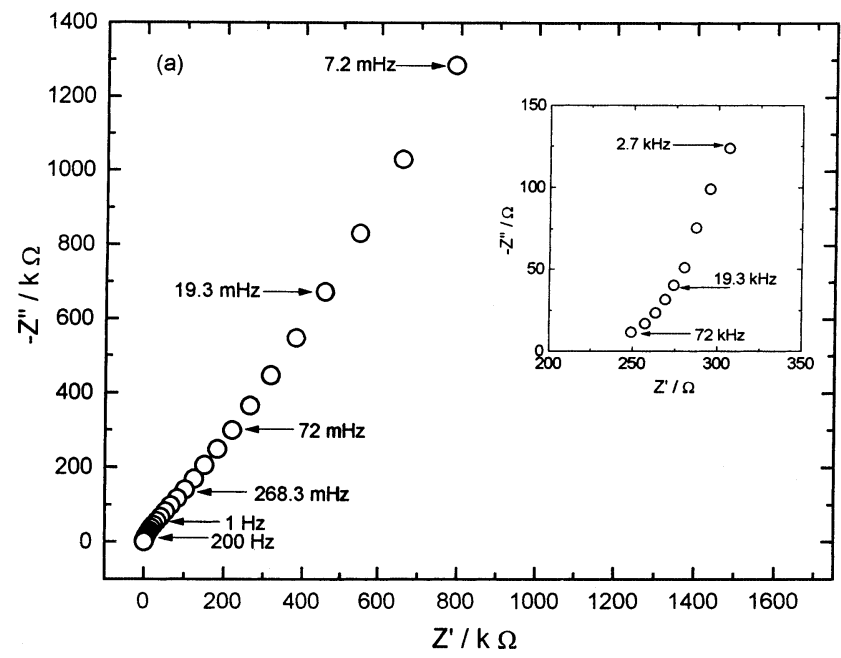

Fig. 1. A.c. impedance spectrum in Nyquist form of a SS/GPE/SS cell at $20{ }^{\circ} \mathrm{C}$. The symbols: $Z^{\prime}$ and $Z^{\prime \prime}$ refer to real and imaginary components, respectively. High frequency part of the spectrum is expanded and shown as the inset. Frequency values for some of the data points are given. Thickness of the GPE $=310 \mu \mathrm{m}$ and area of the SS electrode $=0.5 \mathrm{~cm}^{2}$. Composition of the GPE is PMMA (1.0 $\mathrm{g})$, PC (1.0 g), EC (1.0g) and $\operatorname{MgTr}(0.5 \mathrm{~g})$.
Symmetrical cells, SS/GPE/SS and (SS)Mg/GPE/ $\mathrm{Mg}(\mathrm{SS})$, where SS is stainless steel, were assembled in Ar filled glove box. The cells were held in Teflon holders and contained in air-tight glass containers, which were provided with electrical leads. The ambient temperature of the cells was maintained at $20 \pm 1{ }^{\circ} \mathrm{C}$ in an air-conditioned room. For the purpose of experiments at temperatures in the range from 20 to $80^{\circ} \mathrm{C}$, the cell was heated by means of an electrical heating tape, which was surrounding the glass container, a thermocouple and a temperature controller. Temperature inside the glass container was measured with an accuracy of $\pm 1{ }^{\circ} \mathrm{C}$. The manganese dioxide electrodes were prepared using dried samples of battery grade $\gamma-\mathrm{MnO}_{2}$ (electrolytic manganese dioxide, EMD) [12]. A mixture of EMD (80 wt.\%), graphite powder (10 wt.\%) and PMMA (10 wt.\%) as the binder was thoroughly ground in a mortar and applied on to a nickel grid $\left(10 \times 10 \mathrm{~mm}^{2}\right)$. The nickel grid was subjected to prior degreasing in alkali and etching in diluted $\mathrm{HCl}$. The grid along with the electrode material was heated at $80{ }^{\circ} \mathrm{C}$ for about $5 \mathrm{~min}$ and then compacted at a pressure of 5 tons $\mathrm{cm}^{-2}$. A Mg/GPE/ $\mathrm{MnO}_{2} / \mathrm{GPE} / \mathrm{Mg}$ cell (for brevity, hereafter referred to as $\mathrm{Mg} / \mathrm{GPE}$ / $\mathrm{MnO}_{2}$ cell) was assembled by sandwiching the respective electrodes and the GPE film in a sealed container. Several cells were assembled for the purpose of different experiments and to ensure reproducibility. The symmetrical cells were subjected to a.c. impedance measurements using an electrochemical impedance analyzer (EG\&G PARC model 6310) in the frequency range from $100 \mathrm{kHz}$ to $5 \mathrm{mHz}$ at an excitation signal of $5 \mathrm{mV}$. The impedance data were analyzed by using an electrical equivalent circuit and a non-linear least square fitting (NLLS) program [13], similar to earlier reports [14-16]. Cyclic voltammograms were recorded using a potentiostat/galvanostat (EG\&G PARC model Versastat). Charge/discharge cycling of $\mathrm{Mg} / \mathrm{GPE} / \mathrm{MnO}_{2}$ cells was carried out using either a potentiostat/galvanostat (Eco Chemie model Autolab 30) or a galvanostatic circuit, which consisted of a regulated d.c. power source, a high resistance and an ammeter in series. Cell voltage was measured using a multimeter (Philips model PP 9007).

\section{Results and discussion}

\subsection{A.c. impedance of $S S / G P E / S S$ cell}

Electrochemical impedance spectrum of a SS/GPE/ SS symmetrical cell is shown in Fig. 1 in the Nyquist form. The electrical response of the cell may be explained on the basis of an equivalent circuit shown in Fig. 2(a). The symbols $R_{\mathrm{i}}$ and $R_{\mathrm{b}}$, respectively, refer to resistance of the SS/GPE interface and resistance of the 
(a)

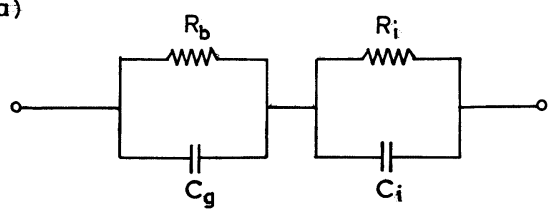

(b)

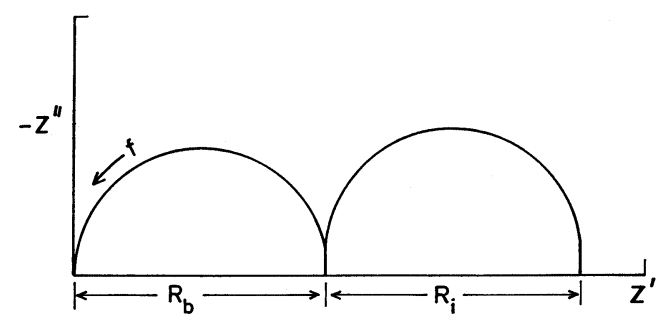

Fig. 2. Electrical equivalent circuit of SS/GPE/SS cell (a) and the corresponding impedance spectrum (b). The symbols $R_{\mathrm{b}}$ and $R_{\mathrm{i}}$ refer to the resistance of the GPE and resistance of the SS/GPE interphase; $C_{\mathrm{g}}$ and $C_{\mathrm{i}}$ refer to capacitance of the GPE and capacitance of the $\mathrm{SS} / \mathrm{GPE}$ interphase, respectively.

Table 1

Specific conductivity $(\sigma)$ of gel polymer electrolytes containing PMMA (1.0 g), MgTr $(0.4 \mathrm{~g})$ and different masses of $(\mathrm{PC}+\mathrm{EC})$ at $20{ }^{\circ} \mathrm{C}$

\begin{tabular}{lr}
\hline Mass of PC+EC $(\mathrm{g})$ & $\sigma\left(\mathrm{S} \mathrm{cm}^{-1}\right)$ \\
\hline 1.0 & $5.9 \times 10^{-5}$ \\
1.5 & $7.56 \times 10^{-5}$ \\
2.0 & $2.1 \times 10^{-4}$ \\
3.0 & $3.0 \times 10^{-4}$ \\
\hline
\end{tabular}

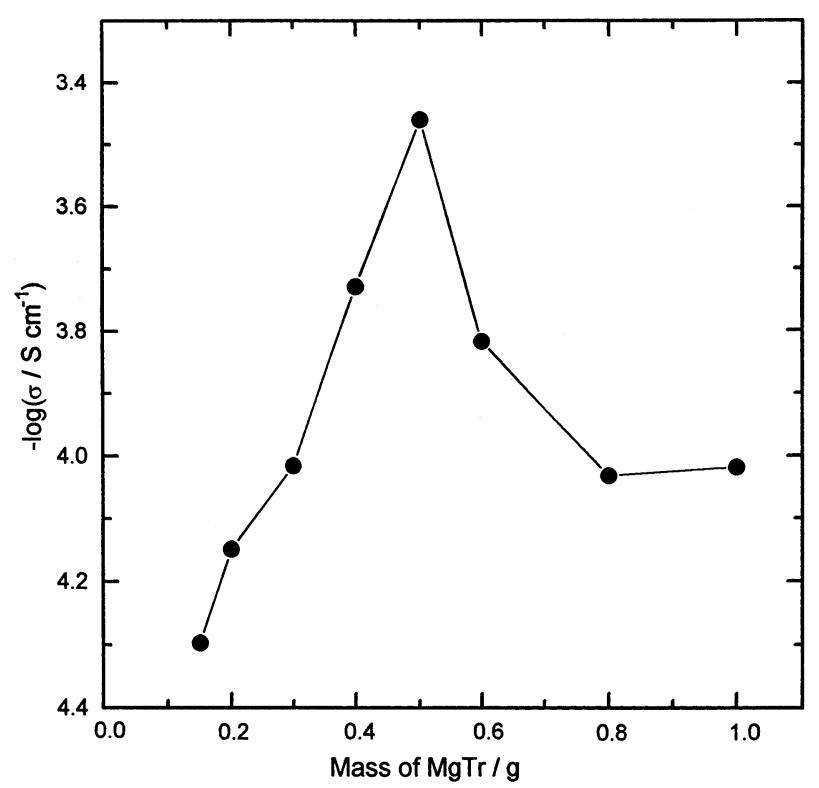

Fig. 3. Specific conductivity $(\sigma)$ of GPE as a function of mass of MgTr in PMMA (1.0 g), PC (1.0 g) and EC (1.0 g) at $20{ }^{\circ} \mathrm{C}$.
GPE, and $C_{\mathrm{i}}$ and $C_{\mathrm{g}}$ refer to capacitance of the SS/GPE interface and geometric capacitance of the GPE. The impedance $(Z)$ of the cell is given in Eq. (1).

$Z=\left(R_{\mathrm{b}}-j / 2 \pi f C_{\mathrm{g}}\right)+\left(R_{\mathrm{i}}-j / 2 \pi f C_{\mathrm{i}}\right)$

where $f$ is a.c. frequency. A typical impedance spectrum corresponding to Eq. (1) is shown in Fig. 2(b), which is characterized by two semicircles. A comparison with the expected spectrum (Fig. 2(b)) suggests that the high frequency semicircle corresponding to the GPE is absent in the experimental spectrum (Fig. 1) since the frequency range $>100 \mathrm{kHz}$ is required for its appearance. Furthermore, the SS behaves as a blocking electrode with a high value of $R_{\mathrm{i}}$ and, therefore, the data corresponding to the SS/GPE interface is not in the form of a semicircle. Resistance $\left(R_{\mathrm{b}}\right)$ of the GPE is obtained from intercept of the high frequency data on the real axis. For the purpose of evaluating $R_{\mathrm{i}}$, the Bode representation of the impedance (not shown) is useful. The total cell resistance $\left(R_{\mathrm{t}}\right)$ can be obtained from the low frequency intercept of modulus of impedance $(|Z|)$. $R_{\mathrm{i}}$ can be obtained from Eq. (2).

$R_{\mathrm{i}}=R_{\mathrm{t}}-R_{\mathrm{b}}$

For the data shown in Eq. (1), the values of $R_{\mathrm{b}}, R_{\mathrm{i}}$ and $R_{\mathrm{t}}$ obtained are $250,1 \times 10^{6}$ and $1 \times 10^{6} \Omega$, respectively.

\subsection{Conductivity and composition of GPE}

From the value of $R_{\mathrm{b}}$ obtained from impedance measurements of SS/GPE/SS cell the specific conductivity $(\sigma)$ of the GPE is calculated using Eq. (3).

$\sigma=l / A R_{\mathrm{b}}$

where $l$ is thickness of the GPE and $A$ is area of SS electrode. From the data shown in Fig. 1, a value of $3.2 \times 10^{-4} \mathrm{~S} \mathrm{~cm}^{-1}$ is obtained for $\sigma$ at $20{ }^{\circ} \mathrm{C}$. The GPE of PMMA possesses a high ionic conductivity due to the presence of a solution of MgTr with PC and EC as solvents. Mechanical strength of the GPE film, however, is rather poor. It was considered necessary that the quantity of liquid components (viz. PC and EC) be at a low level so that the GPE possesses mechanical strength as high as possible. Since the formation of a gel by PMMA requires a minimum quantity of the liquid components, a series of GPE films were prepared by varying the quantity of $\mathrm{PC}$ and $\mathrm{EC}$. It was thus found that the minimum mass ratio of $(\mathrm{PC}+\mathrm{EC})$ to PMMA was 2:1 for a convenient formation of the gel. The gel was not homogeneous and not flexible at lower proportions of $(\mathrm{PC}+\mathrm{EC})$, where as at higher proportions there was an excess of the liquid. The $\sigma$ values of the GPE films with different ratios of $(\mathrm{PC}+\mathrm{EC})$ to PMMA are given in Table 1.

Subsequent to optimization of the liquid components for the formation of a gel, several GPE films were 


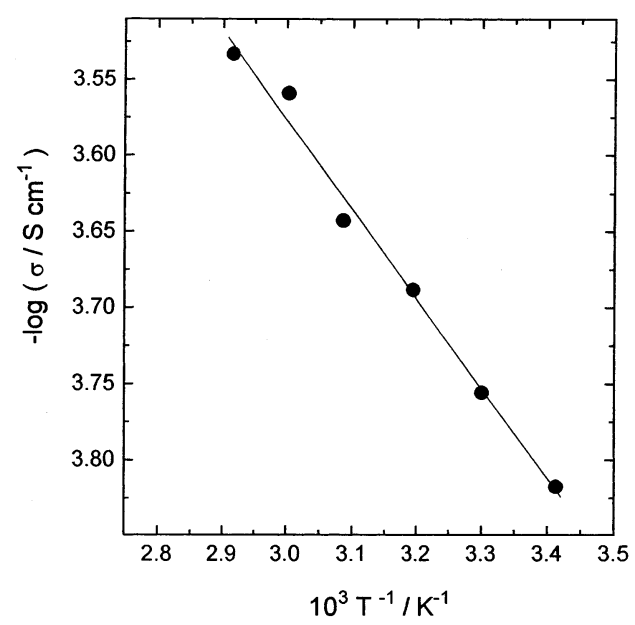

Fig. 4. Arrhenius plot of specific conductivity $(\sigma)$ of the GPE film of optimum Composition.

prepared by varying the concentration of MgTr. The variation in $\sigma$ with $\mathrm{MgTr}$ concentration is shown in Fig. 3. At low concentrations of $\mathrm{MgTr}, \sigma$ is about $5.4 \times 10^{-5} \mathrm{~S} \mathrm{~cm}^{-1}$ and it increases with concentration reaching a maximum value of about $3.75 \times 10^{-4} \mathrm{~S}$ $\mathrm{cm}^{-1}$. This is due to increase in $\mathrm{Mg}^{2+}$ ion concentration. Further increase in concentration of $\mathrm{MgTr}$ results in a decrease in $\sigma$, probably due to the ion-pair formation. Thus the maximum value of $\sigma$ is obtained for PMMA, (PC + EC) and MgTr mass ratio of 1:2:0.5. Several GPE films of varying thickness were prepared with the optimized composition and the average value of $\sigma$ obtained was $(4.2 \pm 0.45) \times 10^{-4} \mathrm{~S} \mathrm{~cm}^{-1}$ at $20{ }^{\circ} \mathrm{C}$.

For the purpose of studying temperature dependence of $\sigma$, the SS/GPE/SS cells with different concentrations of $\mathrm{MgTr}$ in GPE were subjected to a.c. impedance measurements at several temperatures between 20 and $80{ }^{\circ} \mathrm{C}$. In the case of some polymer electrolytes, the

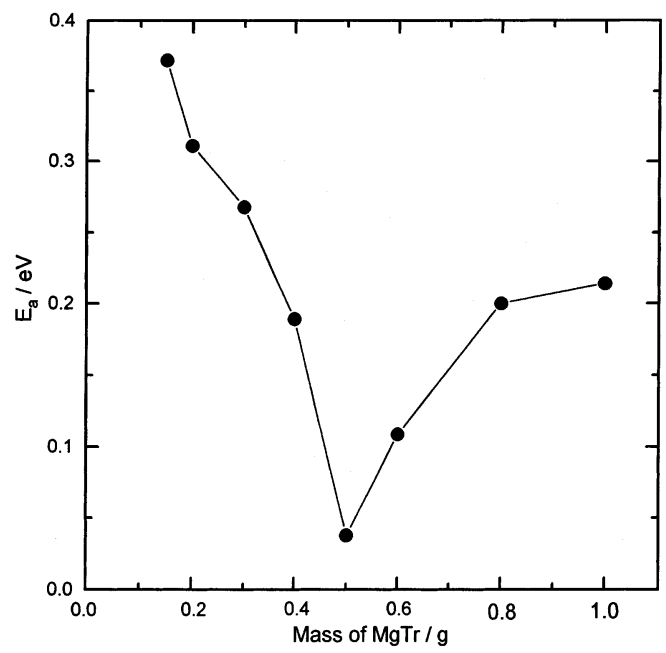

Fig. 5. Variation of activation energy $\left(E_{\mathrm{a}}\right)$ with mass of MgTr in GPE films containing $1.0 \mathrm{~g}$ PMMA, $1.0 \mathrm{~g}$ PC and $1.0 \mathrm{~g} \mathrm{EC}$.

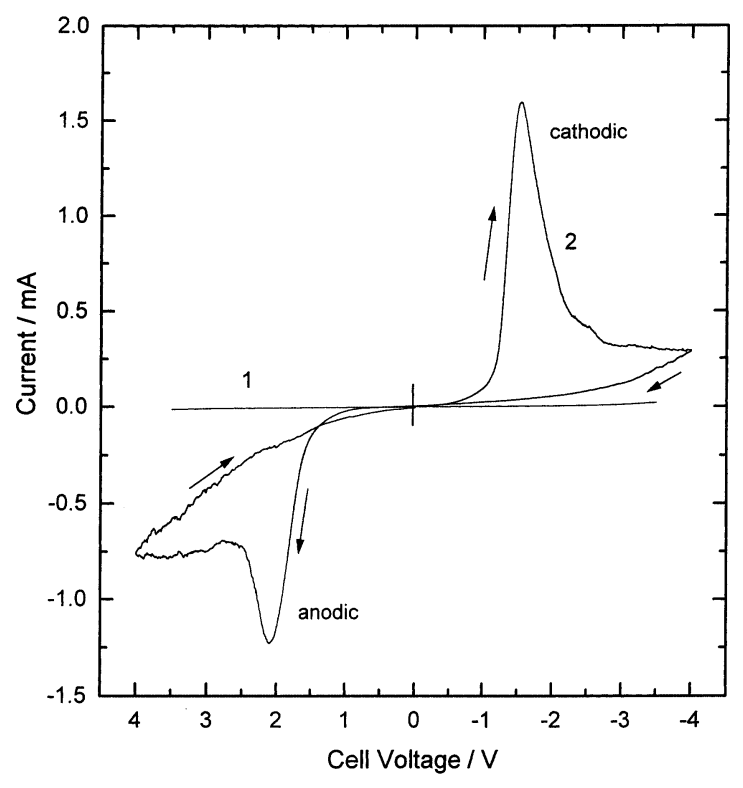

Fig. 6. Cyclic voltammograms of: (1) SS/GPE/SS; and (2) $\mathrm{Mg} / \mathrm{GPE} /$ $\mathrm{Mg}$ symmetrical cells at a scan rate of $5 \mathrm{mV} \mathrm{s}^{-1}$ and at $20{ }^{\circ} \mathrm{C}$. Thickness of the GPE $=250 \mu \mathrm{m}$, area of the SS electrode $=0.5 \mathrm{~cm}^{2}$ and area of the $\mathrm{Mg}$ electrode $=0.9 \mathrm{~cm}^{2}$.

temperature ( $T$ ) dependence of $\sigma$ obeys Arrhenius relationship (Eq. (4)) [17].

$\sigma=A_{\mathrm{o}} \exp \left(-E_{\mathrm{a}} / R T\right)$

where $E_{\mathrm{a}}$ is activation energy, $R$ is gas constant and $A_{\mathrm{o}}$ is pre-exponential factor. The $\sigma$ values of the GPE films obtained in the present study are used to construct $\log \sigma$ versus $1 / T$ plots as shown in Fig. 4 typically for the optimum composition. It is seen that the plot is linear thus suggesting that the Arrhenius equation (Eq. (4)) is valid. Similarly, the data of other compositions of the GPE also followed Arrhenius behaviour. Using the value of the slope and Eq. (4), $E_{\mathrm{a}}$ values calculated are in the range between 0.36 and $0.03 \mathrm{eV}$. The variation of $E_{\mathrm{a}}$ with concentration of $\mathrm{MgTr}$ is shown in Fig. 5. It is interesting to note that the value of $E_{\mathrm{a}}$ is a minimum of $0.038 \mathrm{eV}$ for the GPE of optimum composition. There is an increase in $E_{\mathrm{a}}$ if $\mathrm{MgTr}$ concentration is either decreased or increased. In the case of GPE films made of PAN and $\mathrm{MgTr}$, the value of $E_{\mathrm{a}}$ is about $0.15 \mathrm{eV}$ independent of $\mathrm{MgTr}$ concentration [11]. The

Table 2

Transport number $\left(t_{+}\right)$of $\mathrm{Mg}^{2+}$ ion in the gel polymer electrolyte of PMMA (1.0 g), PC (1.0 g), EC (1.0 g) and $\operatorname{MgTr}(0.5 \mathrm{~g})$ at different temperatures

\begin{tabular}{ll}
\hline$T\left({ }^{\circ} \mathrm{C}\right)$ & $t_{+}$ \\
\hline 20 & 0.55 \\
27 & 0.33 \\
35 & 0.28 \\
45 & 0.14 \\
\hline
\end{tabular}




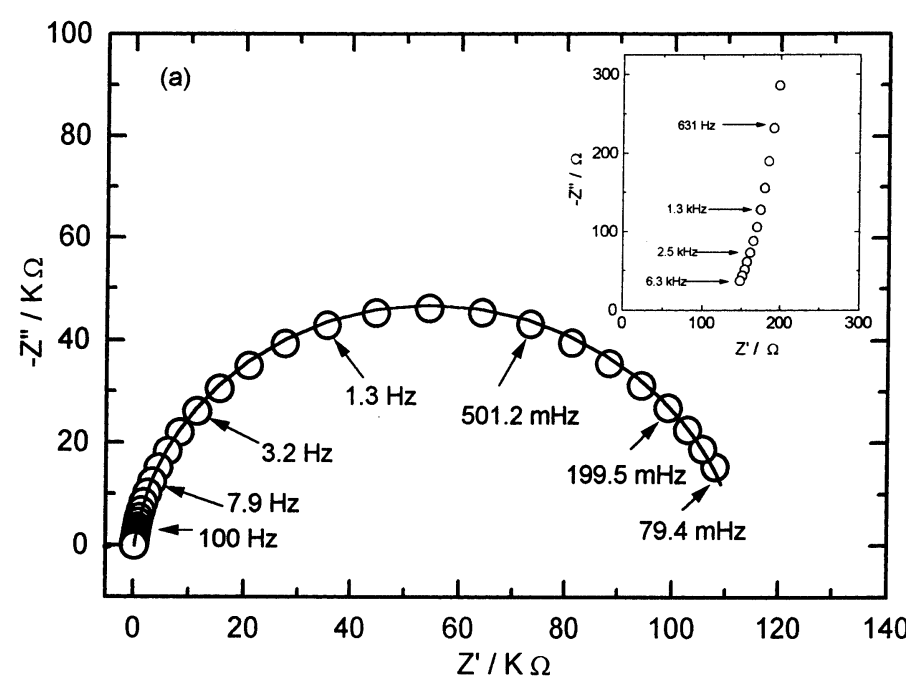

Fig. 7. A.c. impedance spectrum in Nyquist form of a $\mathrm{Mg} / \mathrm{GPE} / \mathrm{Mg}$ cell at $20{ }^{\circ} \mathrm{C}$. The high frequency part of the spectrum is expanded and shown as the inset. The experimental data are shown as circles and the theoretical data from NLLS fit results are shown as solid lines. Thickness of the GPE film $=250 \mu \mathrm{m}$ and area of the $\mathrm{Mg}$ electrode $=0.9 \mathrm{~cm}^{2}$.

value of $E_{\mathrm{a}}$ is as high as $0.92 \mathrm{eV}$ for SPE of PEO and $\mathrm{MgTr}$ and it decreased in the presence of plasticizers [18]. Very low value of $E_{\mathrm{a}}$ suggests that ionic conduction is facile in the GPE of optimum composition.

\subsection{Cyclic voltammetry}

The SS/GPE/SS and $\mathrm{Mg} / \mathrm{GPE} / \mathrm{Mg}$ symmetrical cells were subjected to cyclic voltammetry between -4.0 and $4.0 \mathrm{~V}$ and the voltammograms are shown in Fig. 6. In the case of the SS cell (Fig. 6 curve 1), negligibly small current flows throughout the voltage range and there are no current peaks. It is therefore, inferred that the electrodeposition of $\mathrm{Mg}$ is not facilitated on the SS substrate. Furthermore, the voltammogram reflects a wide voltage window of electrochemical stability of the GPE. The voltammogram of the $\mathrm{Mg} / \mathrm{GPE} / \mathrm{Mg}$ cell (Fig. 6 curve 2) is characterized by a pair of current peaks corresponding to reaction (5).

$\mathrm{Mg}^{2+}+2 \mathrm{e}^{-} \rightleftharpoons \mathrm{Mg}$

The cathodic peak, which appears at $-1.5 \mathrm{~V}$ is due to electrodeposition of $\mathrm{Mg}$ (forward of reaction (5)) on the

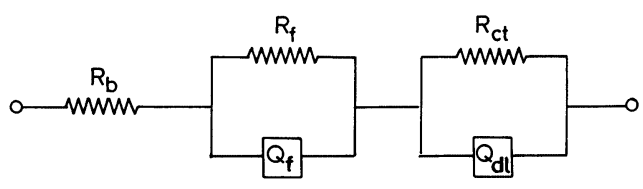

Fig. 8. Electrical equivalent circuit of $\mathrm{Mg} / \mathrm{GPE} / \mathrm{Mg}$ cell. The symbols $R_{\mathrm{b}}, R_{\mathrm{f}}, R_{\mathrm{ct}}$ refer to resistance of the GPE film, resistance of the surface film on $\mathrm{Mg}$ and charge-transfer resistance; $Q_{\mathrm{f}}$ and $Q_{\mathrm{dl}}$ refer to the constant phase elements corresponding to capacitance of surface film on $\mathrm{Mg}\left(C_{\mathrm{f}}\right)$ and double-layer capacitance $\left(C_{\mathrm{dl}}\right)$, respectively.
$\mathrm{Mg}$ substrate, where as the anodic peak, which appears around $2.0 \mathrm{~V}$ is due to oxidation of $\mathrm{Mg}$ (backward of reaction (5)). The peak potential separation $(\Delta E)$ is much larger than $0.03 \mathrm{~V}$, which is expected for a two electron-transfer process. This is because the voltammogram was recorded for the symmetrical cell in the absence of a reference electrode. Although attempts were made to introduce a $\mathrm{Mg}$ foil as a reference electrode into the thin film of the GPE, there was no success as the potentiostat indicated overload, which was probably due to high resistance between the working electrode and the reference electrode. Moreover, difficulties associated with the use of a reference electrode in a thin solid polymer electrolyte film are reported [19]. Since both the electrodes of the $\mathrm{Mg} / \mathrm{GPE} / \mathrm{Mg}$ cell were polarized during the voltage sweep, and also the $\mathrm{Mg}$ surface is covered with a passivating film, the value of $\Delta E$ is very large. Nevertheless, it is understood from Fig. 6 that the electrodeposition and anodic dissolution of $\mathrm{Mg}$ (reaction (5)) is possible on the $\mathrm{Mg}$ substrate unlike on the SS substrate. A comparison of charges associated with the current peaks (Fig. 6 curve 2) suggests that the anodic charge is only $85 \%$ of the cathodic charge. It thus appears that the nature of reaction (5) is quasi reversible on the $\mathrm{Mg}$ electrode.

\subsection{Transport number}

Transport number $\left(t_{+}\right)$of $\mathrm{Mg}^{2+}$ ions in the GPE of optimum composition was measured using the method suggested in the literature [20].

$t_{+}=I_{\mathrm{s}}\left(\Delta V-R_{0} I_{0}\right) / I_{0}\left(\Delta V-R_{\mathrm{s}} I_{\mathrm{s}}\right)$

where $I_{0}$ and $I_{\mathrm{s}}$ are values of current initially and after reaching steady-state, respectively, when a $\mathrm{Mg} / \mathrm{GPE} /$ $\mathrm{Mg}$ cell is potentiostatically polarized by a voltage of $\Delta V ; R_{0}$ and $R_{\mathrm{s}}$ are values of cell resistance measured by a.c. impedance before starting potentiostatic polarization and after the cell reaches steady-state. Accordingly, a $\mathrm{Mg} / \mathrm{GPE} . \mathrm{Mg}$ cell was subjected to chronoamperometric study by applying $\Delta V=0.3 \mathrm{~V}$. It took about $6 \mathrm{~h}$ to reach steady-state and the values of $I_{0}$ and $I_{\mathrm{s}}$ were noted. The cell was subjected to a.c. impedance measurements prior to and afier the chronoamperometric measurements, and the values of $R_{0}$ and $R_{\mathrm{s}}$ were obtained (cf. Section 3.5). The values of the $t_{+}$for several cell temperatures are given in Table 2. At ambient temperature, $t_{+}$is 0.55 and it decreases with an increase of temperature. A similar decrease in $t_{+}$with temperature is reported for $\mathrm{Zn}$ and $\mathrm{Ag}$ salts in SPE media [21].

\subsection{Impedance of $M g / G P E$ interphase}

Impedance spectrum of a $\mathrm{Mg} / \mathrm{GPE} / \mathrm{Mg}$ symmetrical cell consisting of the GPE of optimum composition is 
Table 3

Correlation factors of the fitting of the a.c. impedance spectrum shown in Fig. 7

\begin{tabular}{|c|c|c|c|c|c|c|c|}
\hline Par \# & $R_{\mathrm{b}}$ & $R_{\mathrm{f}}$ & $Q_{\mathrm{f}}$ & $n_{\mathrm{f}}$ & $R_{\mathrm{ct}}$ & $Q_{\mathrm{dl}}$ & $n_{\mathrm{dl}}$ \\
\hline$R_{\mathrm{b}}$ & 1.00 & & & & & & \\
\hline$R_{\mathrm{f}}$ & -0.39 & 1.00 & & & & & \\
\hline$Q_{\mathrm{f}}$ & -0.31 & 0.87 & 1.00 & & & & \\
\hline$n_{\mathrm{f}}$ & -0.46 & 0.93 & 0.67 & 1.00 & & & \\
\hline$R_{\mathrm{ct}}$ & 0.41 & -0.98 & -0.82 & -0.94 & 1.00 & & \\
\hline$Q_{\mathrm{dl}}$ & 0.34 & -0.99 & -0.93 & -0.87 & 0.95 & 1.00 & \\
\hline$n_{\mathrm{dl}}$ & 0.52 & -0.57 & -0.25 & -0.81 & 0.64 & 0.44 & 1.00 \\
\hline
\end{tabular}

shown in Fig. 7. The plot has the shape of a semicircle, unlike the data of the SS/GPE/SS cell (Fig. 1). The high frequency intercept of the real axis (Fig. 7) provides the value of $R_{\mathrm{b}}$ of the GPE. The $\sigma$ values obtained from the impedance data of SS/GPE/SS cell (Fig. 1) and $\mathrm{Mg} /$ GPE/Mg cell (Fig. 7) are nearly the same in magnitude. The $R_{\mathrm{t}}$ value as obtained from the low frequency intercept of the plot (Fig. 7) is about $120 \mathrm{k} \Omega$, which is considerably less than the value obtained for SS/GPE/ SS cells (Fig. 1). A low value of $R_{\mathrm{t}}$ reflects occurrence of the electron-transfer process (reaction (5)) at the $\mathrm{Mg} / \mathrm{GPE}$ interphase.

It is known that alkali and alkaline earth metals are covered with surface films, which provide kinetic stability to the metals. The surface film is considered to behave as an interface, known as solid electrolyte interface (SEI), between the metal and the electrolyte medium [22]. The surface film of a SEI electrode is believed to consist of two layers. A thin adherent layer on the metal, known as passivating layer (PL), and a porous secondary layer (SL) of corrosion products over the PL are composed of compounds of the metal. The PL is ionically conducting and electronically insulating. In the present case also, the $\mathrm{Mg} / \mathrm{GPE}$ interface is considered to consist of surface film, which is characterized by its resistance $\left(R_{\mathrm{f}}\right)$ and capacitance $\left(C_{\mathrm{f}}\right)$, together with the occurrence of reaction (5), which is characterized by charge-transfer resistance $\left(R_{\mathrm{ct}}\right)$ and double-layer capacitance $\left(C_{\mathrm{d} 1}\right)$. The equivalent circuit of the $\mathrm{Mg}$ / $\mathrm{GPE} / \mathrm{Mg}$ cell is shown in Fig. 8. Since the experimental data take the shape of a distorted semicircle, capacitances $C_{\mathrm{f}}$ and $C_{\mathrm{dl}}$ are replaced by constant phase elements (CPE) $Q_{\mathrm{f}}$ and $Q_{\mathrm{dl}}$, respectively. A CPE is defined in admittance form as in Eq. (7).

$Y^{*}=Y_{0}(j \omega)^{n}$

For $n=0$, the CPE represents a resistance with $R=$ $Y_{0}^{-1}$; for $n=1$, a capacitance with $C=Y_{0}$; for $n=0.5$, a Warburg and for $n=-1$, an inductance with $L=$ $Y_{0}^{-1}$ [13]. Since the frequency range of the present study is not high enough to detect the geometric capacitance as discussed previously, $Q_{\mathrm{g}}$ corresponding to $C_{\mathrm{g}}$ is omitted in Fig. 8. The impedance data (Fig. 7) were analyzed for values of the parameters by non-linear least square fitting [13]. The theoretical curves generated using the fit results are shown as solid curves in Fig. 7 and correlation factors of the fitting parameters are given in Table 3. It is seen that the experimental data and the theoretical curves agree well. The values of the impedance parameters obtained for the data shown in Fig. 7 are as follows: $R_{\mathrm{b}}=150 \Omega, R_{\mathrm{f}}=32.2 \mathrm{k} \Omega$, $R_{\mathrm{ct}}=80.3 \mathrm{k} \Omega, Q_{\mathrm{f}}=4.1 \times 10^{-6} \Omega^{-1}, n_{\mathrm{f}}=0.999, Q_{\mathrm{dl}}=$ $3.96 \times 10^{-6} \Omega^{-1}$ and $n_{\mathrm{dl}}=0.875$.

The Butler-Volmer relationship between current density $(i)$ and overpotential $(\eta)$ is generally considered to be valid for an electrochemical reaction also in a SPE medium [19]:

$i=i_{\mathrm{o}}\left(\mathrm{e}^{-2 \alpha F \eta / R T}-\mathrm{e}^{2(1-\alpha) F \eta / R T}\right)$

Eq. (8) is written for reaction (5). The symbols have their usual meanings. Since the a.c. excitation signal used for measuring the impedance data was only $5 \mathrm{mV}$, Eq. (8) is approximated to Eq. (9).

$i_{\mathrm{o}}=R T / 2 F R_{\mathrm{ct}}$

where $R_{\mathrm{ct}}(=-\mathrm{d} \eta / \mathrm{d} i)$ is the charge-transfer resistance. From the value of $144.6 \mathrm{k} \Omega \mathrm{cm}^{2}$ of $R_{\mathrm{ct}}$, the value of $i_{\mathrm{o}}$ obtained for reaction (5) is $0.09 \mu \mathrm{A} \mathrm{cm}{ }^{-2}$.

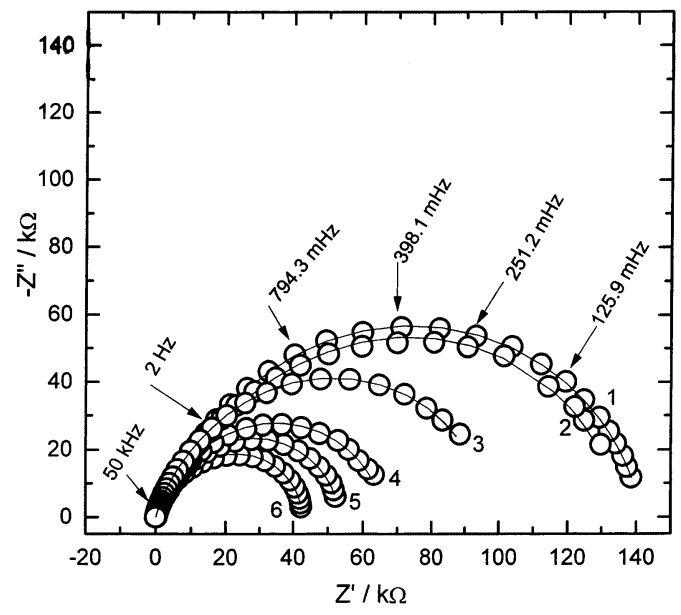

Fig. 9. A.c. impedance spectra of a $\mathrm{Mg} / \mathrm{GPE} / \mathrm{Mg}$ cell at 20 (1), 30 (2), 40 (3), 50 (4), 60 (5) and $70{ }^{\circ} \mathrm{C}(6)$. The experimental data are shown as circles and the theoretical data from NLLS fit results are shown as solid lines. Thickness of the GPE film $=290 \mu \mathrm{m}$ and area of the $\mathrm{Mg}$ electrode $=0.9 \mathrm{~cm}^{2}$. 


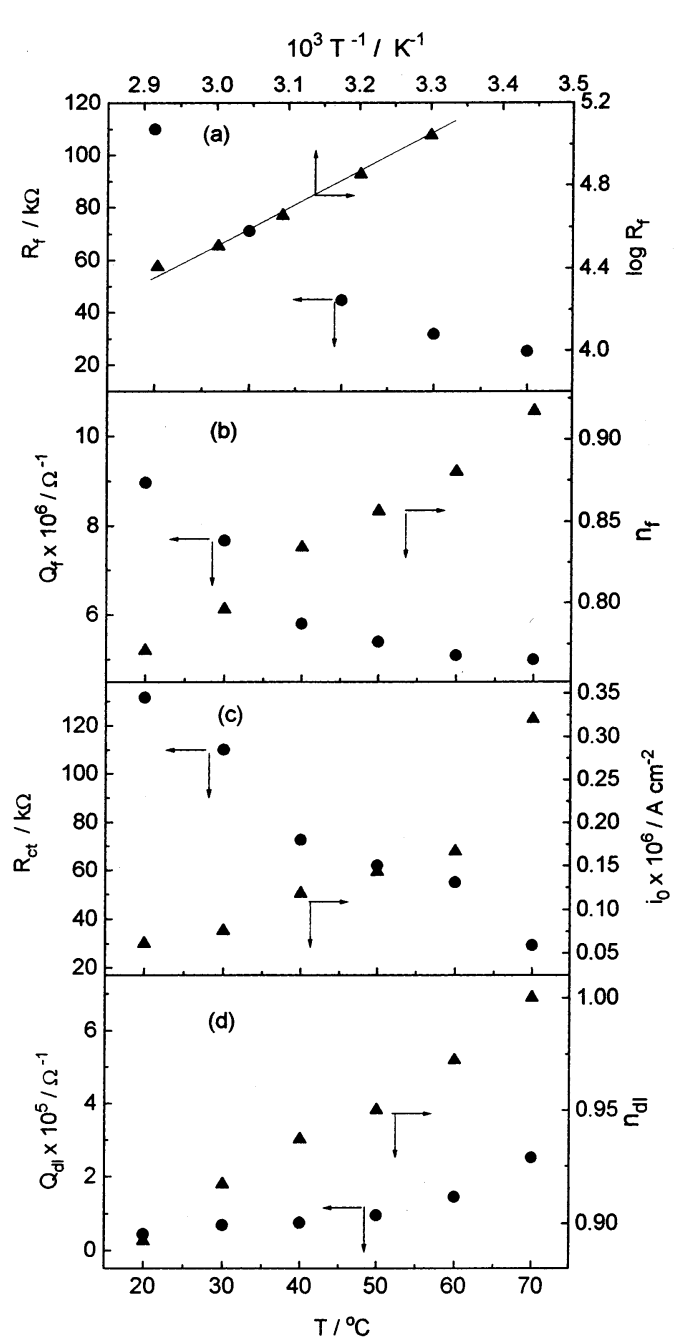

Fig. 10. The variation of impedance parameters of a $\mathrm{Mg} / \mathrm{GPE} / \mathrm{Mg}$ cell with temperature $(T)$. Thickness of the GPE film $=290 \mu \mathrm{m}$ and area of the $\mathrm{Mg}$ electrode $=0.9 \mathrm{~cm}^{2}$.

\subsection{Temperature dependence of $\mathrm{Mg} / \mathrm{GPE} / \mathrm{Mg}$ cells}

In order to study the influence of temperature, a $\mathrm{Mg} / \mathrm{GPE} / \mathrm{Mg}$ cell was subjected to impedance measurements at several temperatures between 20 and $70{ }^{\circ} \mathrm{C}$. The spectra in Nyquist plots decreased in size with an increase of temperature as shown in Fig. 9, suggesting that the interfacial resistance $\left(R_{\mathrm{i}}\right)$ comprising of $R_{\mathrm{f}}$ and $R_{\text {ct }}$ decreases with temperature. The impedance parameters obtained by the NLLS fit procedure are shown in Fig. 10. It is seen that $R_{\mathrm{f}}$ decreases with $T$ thus supporting the ionically conducting nature of the surface film on $\mathrm{Mg}$. Linearity between $\log R_{\mathrm{f}}$ and $1 / T$ suggests Arrhenius bebaviour (Fig. 10(a)). The value of $Q_{\mathrm{f}}$ also decreases with an increase of $T$ (Fig. 10(b)). The variation of $R_{\mathrm{ct}}$ with $T$ also shows a similar trend, and therefore $i_{\mathrm{o}}$ increases with $T$ (Fig. 10(c)). A substantial decrease in the values of $R_{\mathrm{f}}$ and $R_{\mathrm{ct}}$ suggests that the $\mathrm{Mg}$ anode is more conducive for battery application in the GPE at higher temperatures. There is an increase in $Q_{\mathrm{dl}}$ and also $n_{\mathrm{d} 1}$ with $T$ (Fig. 10(d)). An increase in $n_{\mathrm{f}}$ and $n_{\mathrm{dl}}$ (Fig. 10(b) and (d)) suggests that the behaviour of constant phase elements $Q_{\mathrm{f}}$ and $Q_{\mathrm{dl}}$ approaches to the behaviour of capacitors at higher temperatures.

\subsection{Ageing of $M g / G P E / M g$ cells}

Stability of an electrode/electrolyte interface is important in view of battery application over a long duration with extended cycle life. The impedance spectra recorded at several intervals of ageing of a $\mathrm{Mg}$ / GPE/Mg cell are shown in Fig. 11. The size of the impedance spectrum increases with ageing time akin to the studies reported on Li/GPE interphase [6]. There is a decrease in $R_{\mathrm{b}}$ from an initial value of about $150 \Omega$ to about $70 \Omega$ in a few hours of cell assembly following which it remains nearly constant (Fig. 12(a)). Accordingly, $\sigma$ increases from $3 \times 10^{-4} \mathrm{~S} \mathrm{~cm}^{-1}$ to about $7 \times 10^{-4} \mathrm{~S} \mathrm{~cm}^{-1}$ (Fig. 12(d)). There is an increase in $R_{\mathrm{f}}$ and $R_{\mathrm{ct}}$ with ageing as shown in Fig. 12(b) and (c).
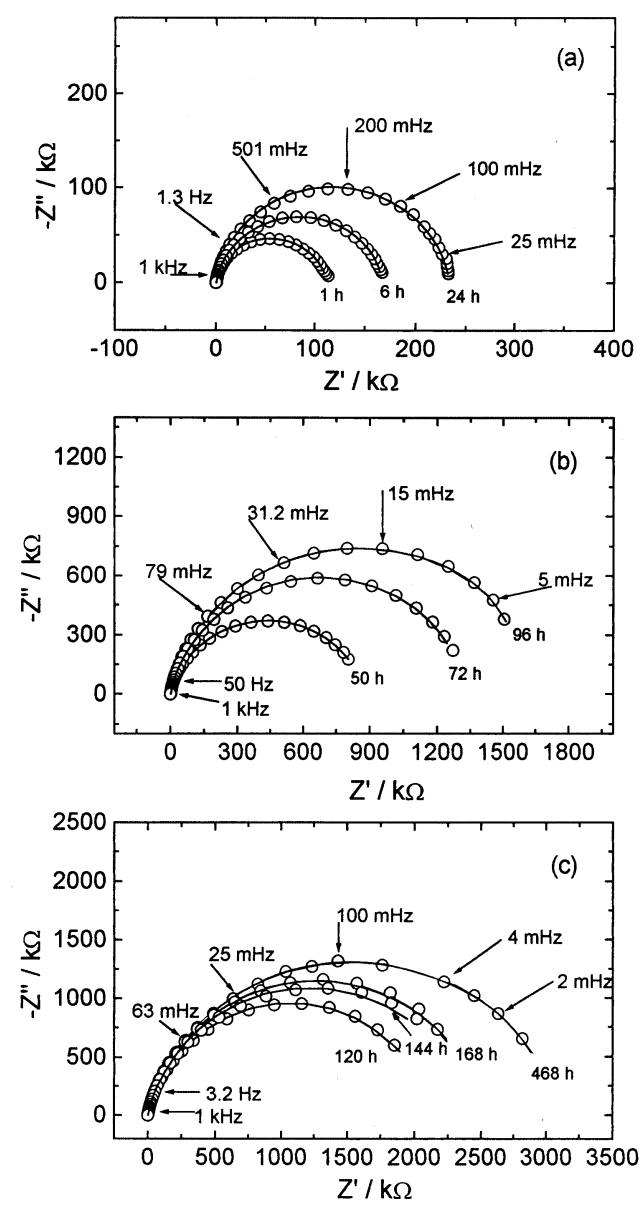

Fig. 11. A.c. impedance spectra of a $\mathrm{Mg} / \mathrm{GPE} / \mathrm{Mg}$ cell at different intervals of ageing at $20{ }^{\circ} \mathrm{C}$. The experimental data are shown as circles and the theoretical data from NLLS fit results are shown as solid lines. Thickness of the GPE film $=450 \mu \mathrm{m}$ and area of the $\mathrm{Mg}$ electrode $=0.9 \mathrm{~cm}^{2}$. 

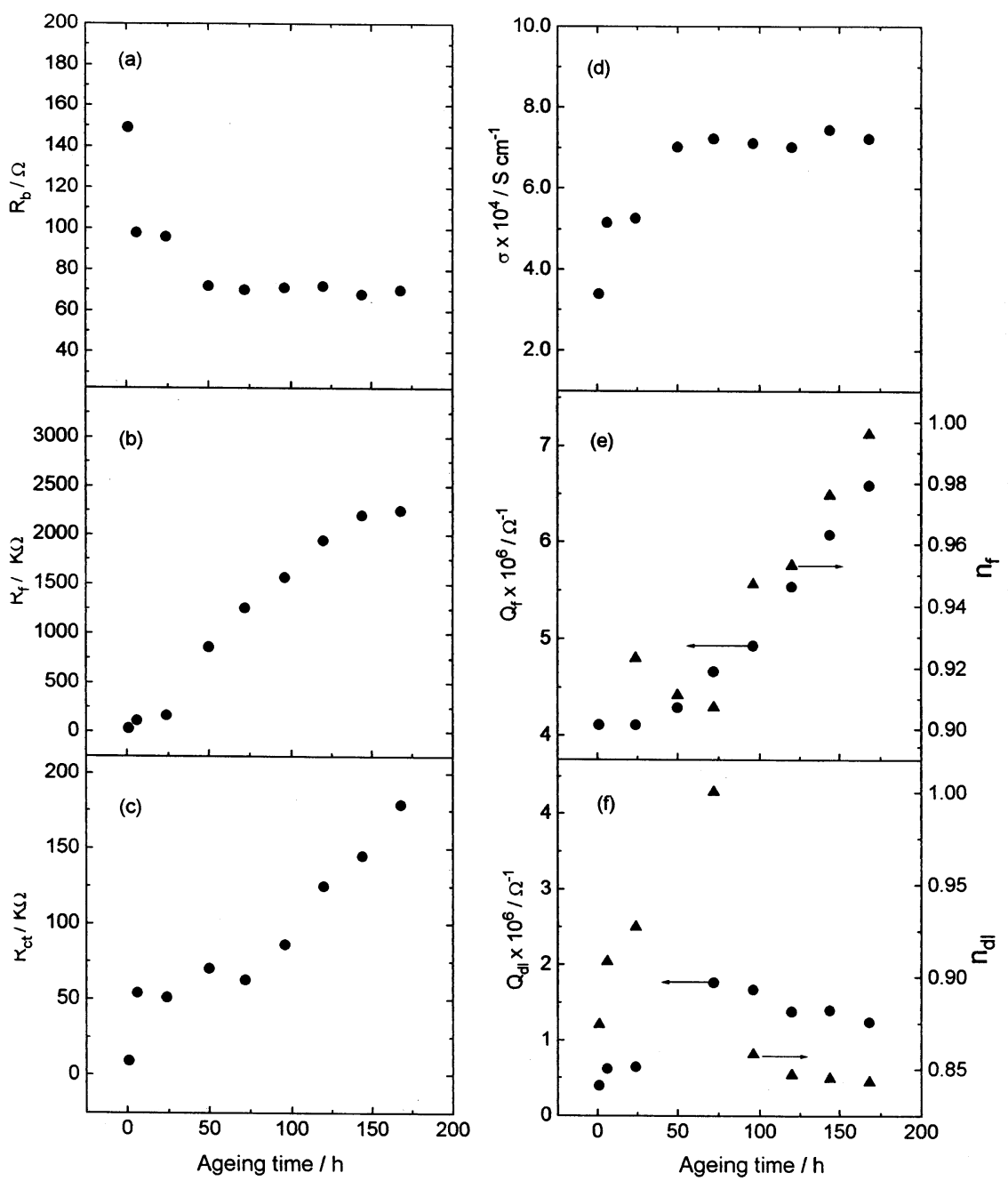

Fig. 12. The variation of the impedance parameters of a $\mathrm{Mg} / \mathrm{GPE} / \mathrm{Mg}$ cell with ageing time. Thickness of the GPE film $=450 \mu \mathrm{m}$ and area of the $\mathrm{Mg}$ electrode $=0.9 \mathrm{~cm}^{2}$.

These results suggest that the surface film on the $\mathrm{Mg}$ grows in thickness during contact with the GPE which is reflected in the enhancement of $R_{\mathrm{f}}$. The increase in $R_{\mathrm{f}}$ in turn impedes the electrochemical process (reaction (5)) thereby causing enhancement in $R_{\mathrm{ct}}$ Formation of surface film comprising magnesium carbonate could probably a cause for increase in $R_{\mathrm{f}}$.

\section{8. $\mathrm{Mg} / \mathrm{GPE} / \mathrm{MnO}_{2}$ cell}

The results reported in the preceding sections reveal that the GPE possesses reasonable conductivity for battery application at ambient temperature and the $\mathrm{Mg} / \mathrm{GPE}$ interface facilitates a reversible $\mathrm{Mg} / \mathrm{Mg}^{2+}$ reaction inspite of the fact that the $\mathrm{Mg}$ is covered with a surface film, which grows in thickness on ageing. In order to demonstrate the application of the GPE, $\mathrm{Mg}$ / $\mathrm{GPE} / \mathrm{MnO}_{2}$ cells were assembled and their performance was evaluated.
A cyclic voltammogram of the $\mathrm{MnO}_{2}$ positive electrode of the $\mathrm{Mg} / \mathrm{GPE} / \mathrm{MnO}_{2}$ is shown in Fig. 13. A reduction peak is present at a cell voltage of about 0.9 $\mathrm{V}$ in the forward scan and an oxidation peak at about $2.9 \mathrm{~V}$ during the reverse scan. The charge associated with the anodic peak is only about $40 \%$ of the cathodic peak, thus, suggesting poor reversibility of the positive electrode reaction. Neverthless, the voltammogram indicates qualitatively that the $\mathrm{MnO}_{2}$ electrode undergoes the reduction and oxidation processes in the GPE medium. The open-circuit voltage of a $\mathrm{Mg} / \mathrm{GPE} / \mathrm{MnO}_{2}$ cell was about $2.0 \mathrm{~V}$. After assembly, the cell was allowed to equilibrate under open circuit conditions for about $2 \mathrm{~h}$ before it was subjected to experiments. During this period, the cell voltage remained nearly non-variant. In our earlier studies on GPE made of polyacrylonitrile, it is found that the $\mathrm{Mg} / \mathrm{GPE} / \mathrm{MnO}_{2}$ cell exhibits two voltage plateau during discharge [12]. The first voltage plateau appears above $1.0 \mathrm{~V}$ and the second one below $1.0 \mathrm{~V}$. Akin to the reactions involved 


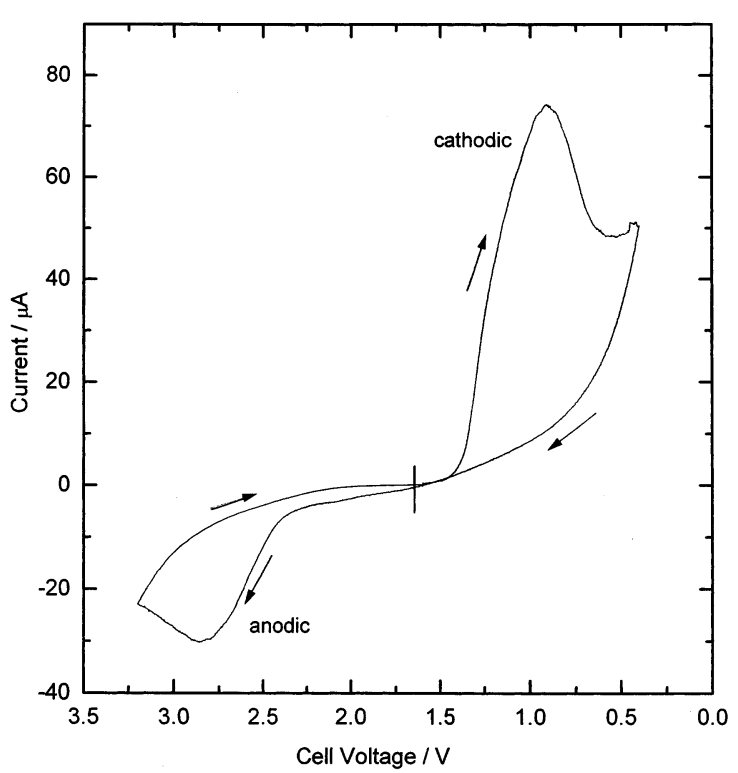

Fig. 13. Cyclic voltammogram at $0.1 \mathrm{mV} \mathrm{s}^{-1}$ scan rate of $\mathrm{MnO}_{2}$ electrode of a $\mathrm{Mg} / \mathrm{GPE} / \mathrm{MnO}_{2}$ cell at $20{ }^{\circ} \mathrm{C}$. Thickness of the GPE film $=350 \mu \mathrm{m}$, electrode area $=0.9 \mathrm{~cm}^{2}$ and mass of $\mathrm{MnO}_{2}=2 \mathrm{mg}$.

in a $\mathrm{Li}-\mathrm{MnO}_{2}$ cell with a non-aqueous liquid electrolyte [23], the following reactions are considered to correspond to the voltage plateau of the $\mathrm{Mg} / \mathrm{GPE} / \mathrm{MnO}_{2}$ cell discharge:

$$
\begin{aligned}
& 2 \mathrm{MnO}_{2}+\mathrm{Mg}^{2+}+2 \mathrm{e}^{-} \rightarrow\left[2 \mathrm{MnO}_{2}^{-} \mathrm{Mg}^{2+}\right] \\
& {\left[2 \mathrm{MnO}_{2}^{-} \mathrm{Mg}^{2+}\right]+\mathrm{Mg}^{2+}+2 \mathrm{e}^{-} \rightarrow\left[2 \mathrm{MnO}_{2}^{2-} 2 \mathrm{Mg}^{2+}\right]}
\end{aligned}
$$

Reaction (10), which corresponds to the first discharge plateau, is the reduction of $\mathrm{MnO}_{2}$ from $\mathrm{Mn}^{4+}$ to

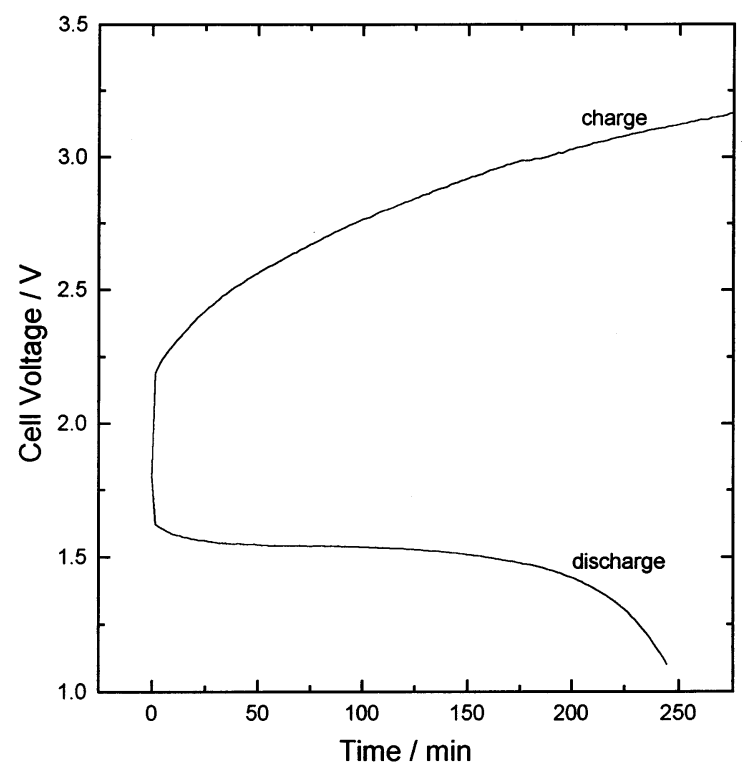

Fig. 14. Variation of voltage of a $\mathrm{Mg} / \mathrm{GPE} / \mathrm{MnO}_{2}$ cell during charging and discharging with a current of $50 \mu \mathrm{A}$. Thickness of the GPE film $=150 \mu \mathrm{m}$, electrode area $=2.5 \mathrm{~cm}^{2}$ and mass of $\mathrm{MnO}_{2}=2 \mathrm{mg}$.

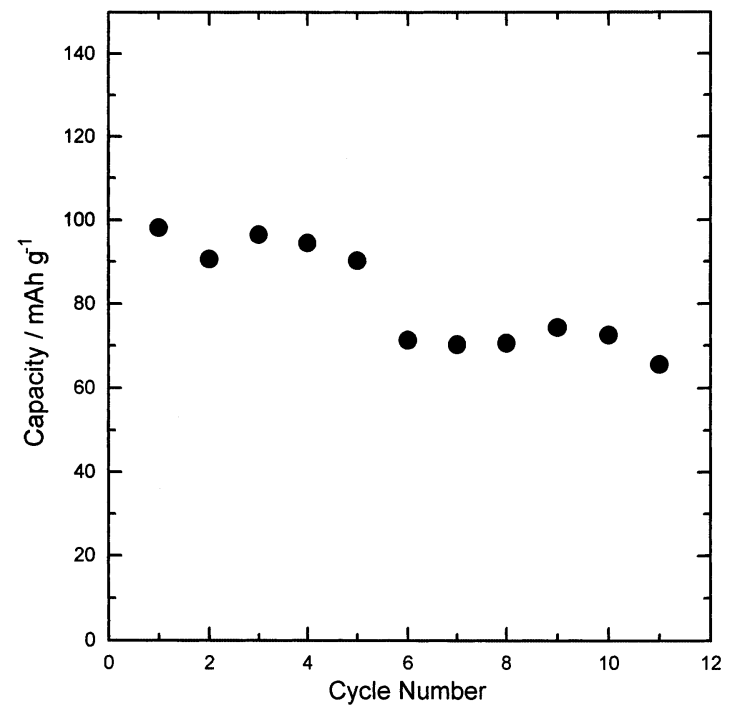

Fig. 15. Cycle-life data of a $\mathrm{Mg} / \mathrm{GPE} / \mathrm{MnO}_{2}$ cell $\mathrm{C} / 4$ rate.

$\mathrm{Mn}^{3+}$. This is accompanied by insertion of $\mathrm{Mg}^{2+}$ ions from the GPE into the $\mathrm{MnO}_{2}$ lattice, which results in the formation of $\left[2 \mathrm{MnO}_{2}^{-} \mathrm{Mg}^{2+}\right]$. This product undergoes further reduction from $\mathrm{Mn}^{3+}$ to $\mathrm{Mn}^{2+}$ in reaction (11), which corresponds to the second voltage plateau. It was found that the cell could not be recharged if it was discharged below $1.0 \mathrm{~V}$ suggesting that Reaction 11 impedes rechargeability of the $\mathrm{MnO}_{2}$ positive electrode [12]. Therefore, the $\mathrm{Mg} / \mathrm{GPE} / \mathrm{MnO}_{2}$ cell in the present study also is subjected to discharge to a cut-off voltage of $1.1 \mathrm{~V}$.

A typical charge/discharge curves of a $\mathrm{Mg} / \mathrm{GPE} /$ $\mathrm{MnO}_{2}$ cell are shown in Fig. 14. Since the cell is assembled in charged condition, it is first subjected to discharge at $\mathrm{C} / 4$ rate. The discharge curve is fairly flat over a long duration of charge. The discharge capacity obtained is about $90 \mathrm{mAh} \mathrm{g}^{-1}$ of $\mathrm{MnO}_{2}$. When charged by the same magnitude of charge, the cell voltage increased to $3.1 \mathrm{~V}$ (Fig. 14). With an increase in cycle number, however, it was found that the discharge curve exhibits a voltage dip, which is similar to the delay-time of magnesium-based aqueous batteries [24]. Also, the charging voltage gradually increased. These processes are attributed to the $\mathrm{Mg} / \mathrm{GPE}$ interface, where the surface film grows in thickness during repeated cycling. The thick surface film in turn tends to passivate the $\mathrm{Mg}$ electrode. The cycle-life data of a $\mathrm{Mg} / \mathrm{GPE} / \mathrm{MnO}_{2}$ cell is shown in Fig. 15. An average discharge capacity of about $90 \mathrm{mAh} \mathrm{g}^{-1}$ of $\mathrm{MnO}_{2}$ is obtained during the initial five charge/discharge cycles. Subsequently, the discharge capacity starts decreasing. Since the cell voltage exceeded $5.0 \mathrm{~V}$ during charging subsequent to about 10 cycles, further cycling of the cell could not be continued. This value of voltage is a safe voltage window for the GPE. 


\section{Conclusions}

A gel polymer electrolyte film of PMMA and $\mathrm{MgTr}$ is studied for ionic conductivity, transport number, interfacial stability and used for a solid-state rechargeable magnesium cell. The composition of the GPE is optimized in view of minimum quantity of the liquid components (propylene carbonate and ethylene carbonate) required for gel formation and maximum conductivity. The specific conductivity $(\sigma)$ of the GPE of optimum composition is $(4.2 \pm 0.45) \times 10^{-4} \mathrm{~S} \mathrm{~cm}^{-1}$ at $20{ }^{\circ} \mathrm{C}$ with an activation energy of $0.038 \mathrm{eV}$. Discharge capacity of about $90 \mathrm{mAh} \mathrm{g} \mathrm{g}^{-1}$ of $\mathrm{MnO}_{2}$ is obtained from $\mathrm{Mg} / \mathrm{GPE} / \mathrm{MnO}_{2}$ cells. On repeated charge/discharge cycling of the cell, the discharge capacity decreases and the problems associated with passivat ion of $\mathrm{Mg}$ surface limit the cycle-life of the $\mathrm{Mg} / \mathrm{GPE} / \mathrm{MnO}_{2}$ cells.

\section{Acknowledgements}

Financial support from the Council of Scientific and Industrial Research, Government of India (Project No: 01(1505)/98/EMR-II) is gratefully acknowledge.

\section{References}

[1] P.V. Wright, Br. Polym. J. 7 (1975) 319.

[2] M.B. Armand, J.M. Chabagno, M. Duclot, in: P. Vashista, J.N. Munday, G.K. Shenoy (Eds.), Fast Ion Transport in Solids, Elsevier, North Holland, 1979, p. 131.

[3] F.M. Gray, Solid Polymer Electrolytes-Fundamentals and
Technological Applications, VCH Publishers, New York, 1991, p. 1.

[4] N. Munichandraiah, L.G. Scanlon, R.A. Marsh, B. Kumar, A.K. Sircar, J. Appl. Electrochem. 25 (1995) 857.

[5] K.M. Abraham, M. Alamgir, J. Electrochem. Soc. 137 (1990) 1657.

[6] N. Munichandraiah, G. Sivasankar, L.G. Scanlon, R.A. Marsh, J. Appl. Polym. Sci. 65 (1997) 2191.

[7] J.L. Robinson, in: N.C. Cahoon, G.W. Heise (Eds.), The Primary Battery, vol. II, John Wiley, 1976, p. 149.

[8] A. Patrick, M. Glasse, R. Latham, R. Linford, Solid State lonics $18 \& 19$ (1986) 1063.

[9] P. Novak, R. Imhof, O. Haas, Electrochim. Acta 45 (1999) 351.

[10] G. Girish Kumar, N. Munichandraiah, Electrochim. Acta 44 (1999) 2663.

[11] G. Girish Kumar, N. Munichandraiah, Solid State Ionics 128 (2000) 203.

[12] G. Girish Kumar, N. Munichandraiah, J. Power Sources 91 (2000) 151.

[13] B.A. Boukamp, Equivalent Circuit Manual, University of Twente, AE Enechede, 1989, p. 1.

[14] N. Munichandraiah, L.G. Scanlon, R.A. Marsh, J. Power Sources 72 (1998) 203.

[15] P. Elumalai, H.N. Vasan, N. Munichandraiah, J. Solid State Electrochem. 3 (1999) 470.

[16] R. Shalini, N. Munichandraiah, A.K. Shukla, J. Solid State Electrochem. 3 (1999) 397.

[17] M.B. Armand, in: J.R. MacCallum, C.A. Vincent (Eds.), Polymer Electrolyte Reviews, vol. 1, Elsevier, London, 1987, p. 1.

[18] O. Girish Kumar, N. Munichandraiah, J. Electroanal. Chem. 495 (2000) 42.

[19] N. Munichandraiah, L.G. Scanlon, R.A. Marsh, B. Kumar, A.K. Sircar, J. Electroanal. Chem. 379 (1994) 495.

[20] J. Evans, C.A. Vincent, P.G. Bruce, Polymer 28 (1987) 2324.

[21] H. Dai, T.A. Zawodzinski, J. Electroanal. Chem. 459 (1998) 111.

[22] E. Peled, in: J.P. Gabano (Ed.), Lithium Batteries, Academic Press, London, 1983, p. 43.

[23] H. Ikeda, in: J.P. Gabano (Ed.), Lithium Batteries, Academic Press, London, 1983, p. 169.

[24] D. Linden, Hand Book of Batteries, McGraw Hill, 1995, pp. $9-11$. 